\title{
Genotypic Profiling of Bacillus cereus Recovered from Some Retail Foods in Ogun State, Nigeria, and Their Phylogenetic Relationship
}

\author{
Titilayo O. Adesetan, ${ }^{1,2}$ Moses O. Efuntoye, ${ }^{1}$ and Olubukola O. Babalola $\mathbb{D}^{2}$ \\ ${ }^{1}$ Department of Microbiology, Olabisi Onabanjo University, PMB 2002, Ago-Iwoye, Ogun State, Nigeria \\ ${ }^{2}$ Food Security and Safety Niche, Faculty of Natural and Agricultural Sciences, North-West University, Private Bag X2046, \\ Mmabatho 2735, South Africa \\ Correspondence should be addressed to Olubukola O. Babalola; olubukola.babalola@nwu.ac.za
}

Received 19 November 2019; Revised 19 June 2020; Accepted 24 August 2020; Published 14 September 2020

Academic Editor: Clemencia Chaves Lopez

Copyright (C) 2020 Titilayo O. Adesetan et al. This is an open access article distributed under the Creative Commons Attribution License, which permits unrestricted use, distribution, and reproduction in any medium, provided the original work is properly cited.

\begin{abstract}
Identifying Bacillus cereus with conventional methods is neither specific nor rapid because of the close relatedness of the B. cereus group, hence the need for molecular methods. Genotypic profiling of B. cereus isolates from food was obtained by Random Amplified Polymorphic DNA-polymerase chain reaction (RAPD-PCR) using OPR13 primer. A dendrogram was drawn with the Numerical Taxonomy System of Statistic (NTSYS) software. Thirty of the isolates were subjected to molecular identification by $16 \mathrm{~S}$ rDNA sequencing. The thirty sequences were deposited in GenBank for accession number. Phylogenetic relationship of the 16S rDNA sequence obtained was carried out with the Multiple Alignment using Fast Fourier Transform (MAFFT) software version 7.0. The evolutionary tree was drawn using the Molecular Evolutionary Genetics Analysis (MEGA 6) software. The dendrogram generated for the RAPD profile showed that all the strains are closely related, with a similarity coefficient of $70 \%$. The isolates were confirmed with $16 \mathrm{~S}$ rDNA sequencing as B. cereus. The thirty sequences deposited in GenBank were given accession numbers: KX574760-KX574769, KX610811-KX610820, MT757957-MT757963, and MT772282-MT772284. By comparing the phylogenetic relationship, eleven of the strains did not cluster with the reference strains from the GenBank but form distinct clades, which means they are likely to be of different ancestors. Conventional methods rarely differentiate bacteria of the same species into clade, neither can it describe their ancestral lineage. Therefore, it is important to employ molecular methods in identifying bacteria to give detailed information about them.
\end{abstract}

\section{Introduction}

Bacillus cereus is Gram-positive rod, motile with peritrichous flagella, and ubiquitous. It can multiply in soil [1] and has also been found in food [2-4]. It survives adverse conditions through endospore formation $[2,5]$. Spores are more resistant to dry heat and radiation than vegetative cells, and resistance to heat is more considerable in reduced water activity food [6]. The $B$. cereus group is now made up of seven members [7] in which B. cereus, B. anthracis, and $B$. thuringiensis are the most significant and are closely related [8]. Therefore, identifying members of the $B$. cereus group with biochemical or physiological characteristics is difficult because these characteristics complicate their accurate peculiarity [9]. Biochemical tests do not give distinct differentiation among the groups, but molecular techniques provide fast and accurate identification of the microorganisms [10]. Desai and Varadaraj [3] used polymerase chain reaction (PCR) to confirm twelve isolates as $B$. cereus out of twenty-six isolates previously characterized as $B$. cereus with the conventional method.

Molecular methods such as Random Amplified Polymorphic DNA (RAPD) [11], Multilocus Enzyme Electrophoresis (MLEE) [12], Amplified Fragment Length Polymorphism [13], and Multilocus Sequence Typing (MLST) [14-16] have been found useful in the study of $B$. cereus.

RAPD, which is a form of PCR, is used to study the genetic diversity of an individual. The short RAPD primers of 10 nucleotides are used to amplify the random sequences of the targeted DNA with low temperature during the 
annealing stage. It is a widely used tool in the study of genetic diversity, population and evolutionary genetics, animalplant-microbe relationships, plant and animal breeding, pesticide/herbicide resistance, and forensic studies [17-19].

Phylogenetics has made it possible to study the evolutionary history and associations that exist among individuals and groups of organisms, e.g., species, population, or genes. Phylogenetic inference is used to ascertain such association, and the outcome is represented with a phylogenetic tree. The three main inference methods for deducing molecular phylogenies are maximum parsimony, maximum likelihood, and pairwise distances [20]. Phylogeny is presently used in many disciplines such as molecular biology, epidemiology, genetics, ecology, conservation biology, evolution, and forensics.

In Nigeria, foods are retailed by people with little or no knowledge about personal hygiene. Vegetables are sometimes put on the bare floor and handled with bare hands before being sold to consumers. Cooked foods like rice and spaghetti sometimes had contact with the hands of the seller when the spoons and fork used in taking the food are supported with bare hands that have been used in handling money laden with pathogenic bacteria. Smoked fish and hides are exposed to dust, flies and sold with bare hands to consumers. Fried meats are sold inside old newspapers, which might have been contaminated. Knowing fully well that B. cereus has been described as a volatile human pathogen, there is need to confirm the isolates recovered from these retailed foods as $B$. cereus using $16 \mathrm{~S}$ rDNA sequencing, to carry out genotypic profiling of the isolates to confirm if strains in retailed foods are the same, and to determine the relationship of some of the genes with closely related genes in GenBank.

\section{Materials and Methods}

2.1. Extraction of Genomic DNA. One hundred B. cereus isolates from some retailed foods previously identified with biochemical tests were randomly selected for further confirmation with molecular methods. Each bacterial isolate was subcultured on Luria-Bertani Agar (Merck, South Africa) and incubated at $37^{\circ} \mathrm{C}$ for $18-24$ hours. Genomic DNA was extracted using the Zymo Soil DNA kit (Zymo Research, USA) by following the manufacturer's instructions written in the manual.

2.2. Primers Employed in This Study. The primers employed were synthesized by IDT (Integrated DNA Technology, USA). The primers are F1/R2 (F1-5' - AGA GTT TGA TCI TGG CTC AG-3'; R2 5'-ACG GIT ACC TTG TTA CGA CTT-3') [21] used for $16 \mathrm{~S}$ rDNA identification while OPR 13 (5'- GGA CGA CAA G-3') [22] was used for genetic profiling. The primers were reconstituted with Tris/EDTA buffer according to the manufacturer's instruction.

2.3. Genetic Typing of Bacillus cereus with RAPD-PCR. The OPR13 primer was used for the amplification of random segments of the genomic DNA of Bacillus strains. The RAPDPCR assay was performed in a reaction volume of $25 \mu \mathrm{l}$ containing $12.5 \mu \mathrm{l}$ Master mix, $11 \mu \mathrm{l}$ nuclease-free water, $0.5 \mu \mathrm{l}$ primer, and $1 \mu \mathrm{l}$ DNA template. The PCR cycles consisted of an initial denaturation step at $94^{\circ} \mathrm{C}$ for $4 \mathrm{~min}$, then 40 cycles comprising DNA denaturation at $94^{\circ} \mathrm{C}$ for $1 \mathrm{~min}$, primer annealing at $35^{\circ} \mathrm{C}$ for $1 \mathrm{~min}$, and DNA extension at $72^{\circ} \mathrm{C}$ for $2 \mathrm{~min}$, then a final extension step at $72^{\circ} \mathrm{C}$ for $5 \mathrm{~min}$ [23]. RAPD-PCR bands were separated by electrophoresis in a $2.0 \%(\mathrm{w} / \mathrm{v})$ agarose gel (LASEC) containing SYBR safe stain (Life Technologies, Thermofisher), immersed in Tris/Acetic acid/EDTA (TAE) (BioRad, USA) buffer, run at $80 \mathrm{~V}$ for 90 min. Molecular Ruler (Thermofisher) 1kb base pairs (bp) ladder was used as a molecular weight marker. After the migration of DNA bands, the gel was photographed on the Gel Doc 2000 Image analyzer (BioRad, USA).

2.4. Analysis of RAPD-PCR Profile. Each gel was examined, and the presence or absence of polymorphic bands in individual lanes was scored 1 and 0 , respectively. The scored bands were subjected to the Numerical Taxonomy System of Statistic (NTSYS) software. In NTSYS analysis, the scatter diagram of the scored bands is useful in revealing a grouping.

2.5. 16S rDNA Identification. The primer set F1/R2 was used for the identification. They were performed in reaction mixtures containing $25 \mu \mathrm{l}$ Master mix, $22 \mu \mathrm{l}$ nuclease-free water, $1.0 \mu \mathrm{l}$ primer, and $2 \mu \mathrm{l}$ template DNA making a final volume of $50 \mu \mathrm{l}$. The PCR amplification was performed in a thermal cycler (C1000 Touch, BioRad) with the following conditions: initial denaturation at $96^{\circ} \mathrm{C}$ for 5 minutes, followed by 30 cycles at $96^{\circ} \mathrm{C}$ for 45 seconds, annealing at $56^{\circ} \mathrm{C}$ for 30 seconds, extension at $72^{\circ} \mathrm{C}$ for 2 minutes, and a final extension at $72^{\circ} \mathrm{C}$ for 5 minutes. The PCR product was analyzed and viewed as described above.

2.6. Sequencing of the PCR Product. Thirty PCR products from 16S rDNA were submitted to Inqaba Biotechnical Industrial (Pty) Ltd, Pretoria, South Africa, for sequencing. The PCR products were sequenced in the forward and reverse directions on the ABI PRISM ${ }^{\mathrm{TM}} 3500 x \mathrm{x}$ Genetic Analyser. Purified sequencing products were analyzed using CLC Main Workbench 7 followed by a BLAST search in the National Centre for Biotechnology Information (NCBI). The thirty sequences were deposited in GenBank for accession number.

2.7. Phylogenetic Analysis. $16 \mathrm{~S}$ rDNA gene of the $B$. cereus was also used for the phylogenetic analyses in order to establish the relationship among them. The search for possible reference nucleotide sequences in the NCBI GenBank database was achieved by using the partial sequences from the $16 \mathrm{~S}$ rDNA of Bacillus cereus [24]. Multiple alignments of nucleotide sequences were obtained with the software Multiple Alignment using Fast Fourier Transform (MAFFT) version 7.0 [25], while two main methods distance-based and character-based were employed in drawing the tree using Molecular Evolutionary Genetics Analysis 6 (MEGA 6) [26]. 


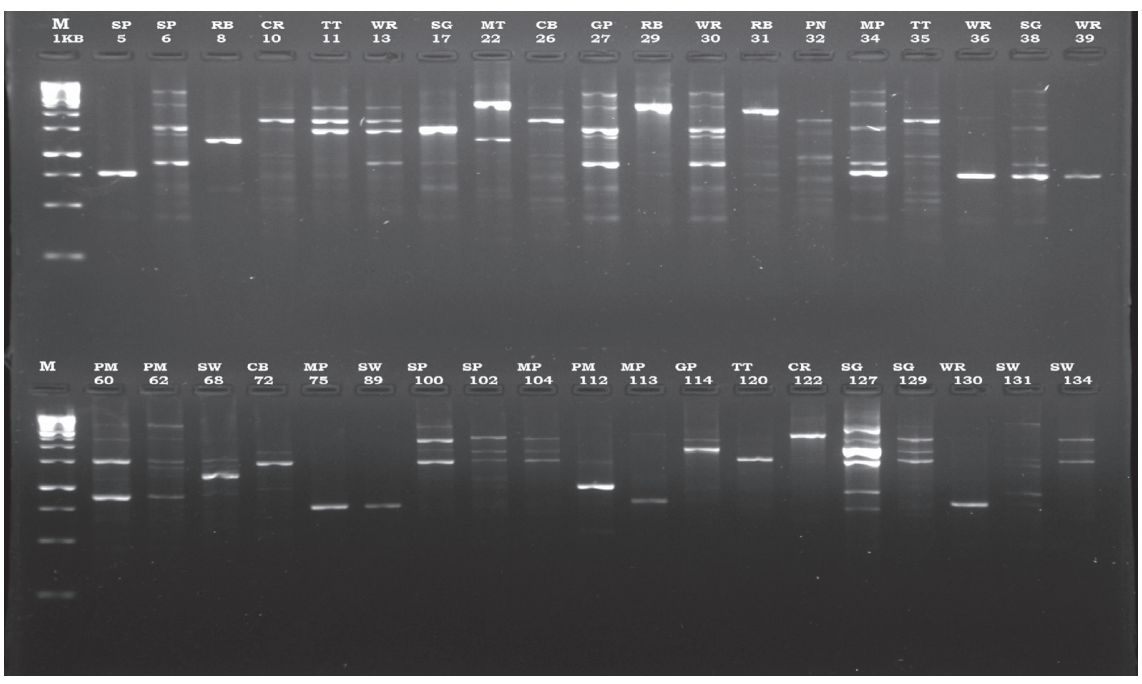

(a)

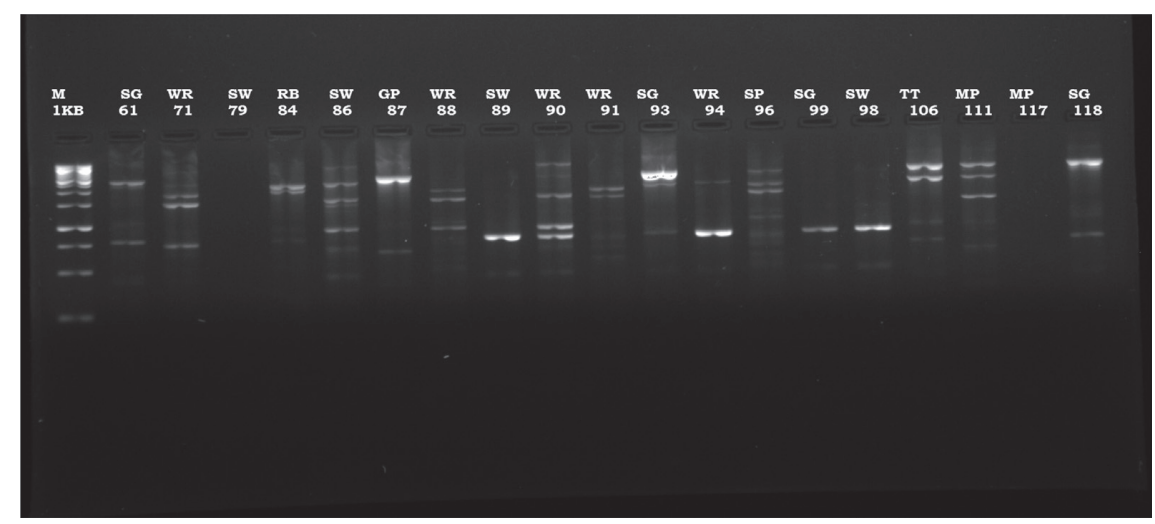

(b)

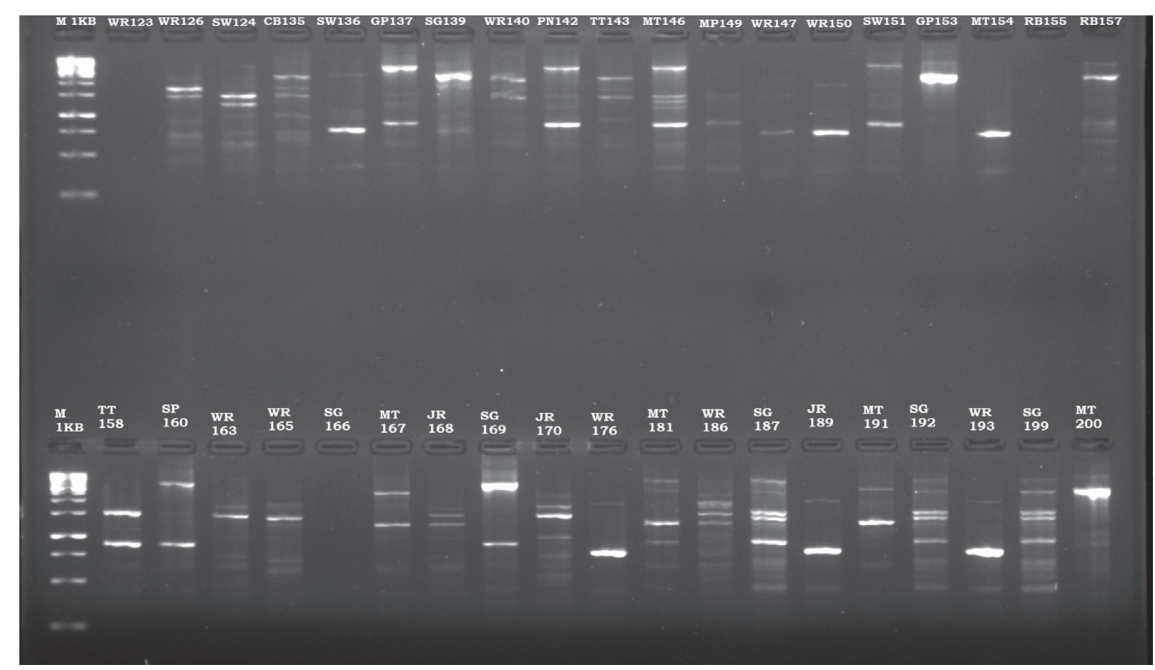

(c)

FIGURE 1: Agarose gel electrophoresis for RAPD-PCR profiles obtained with primer OPR13 for strains in the B. cereus group. M: marker, WR: white rice, JR: jollof rice, TT: smoked titus, GP: green pea, SG: spaghetti, RB: runner bean, MP: meat pie, CR: carrot, MT: meat, CB: cabbage, SW: smoked African chad, SP: sweet pepper, and PN: smoked blue whiting. 


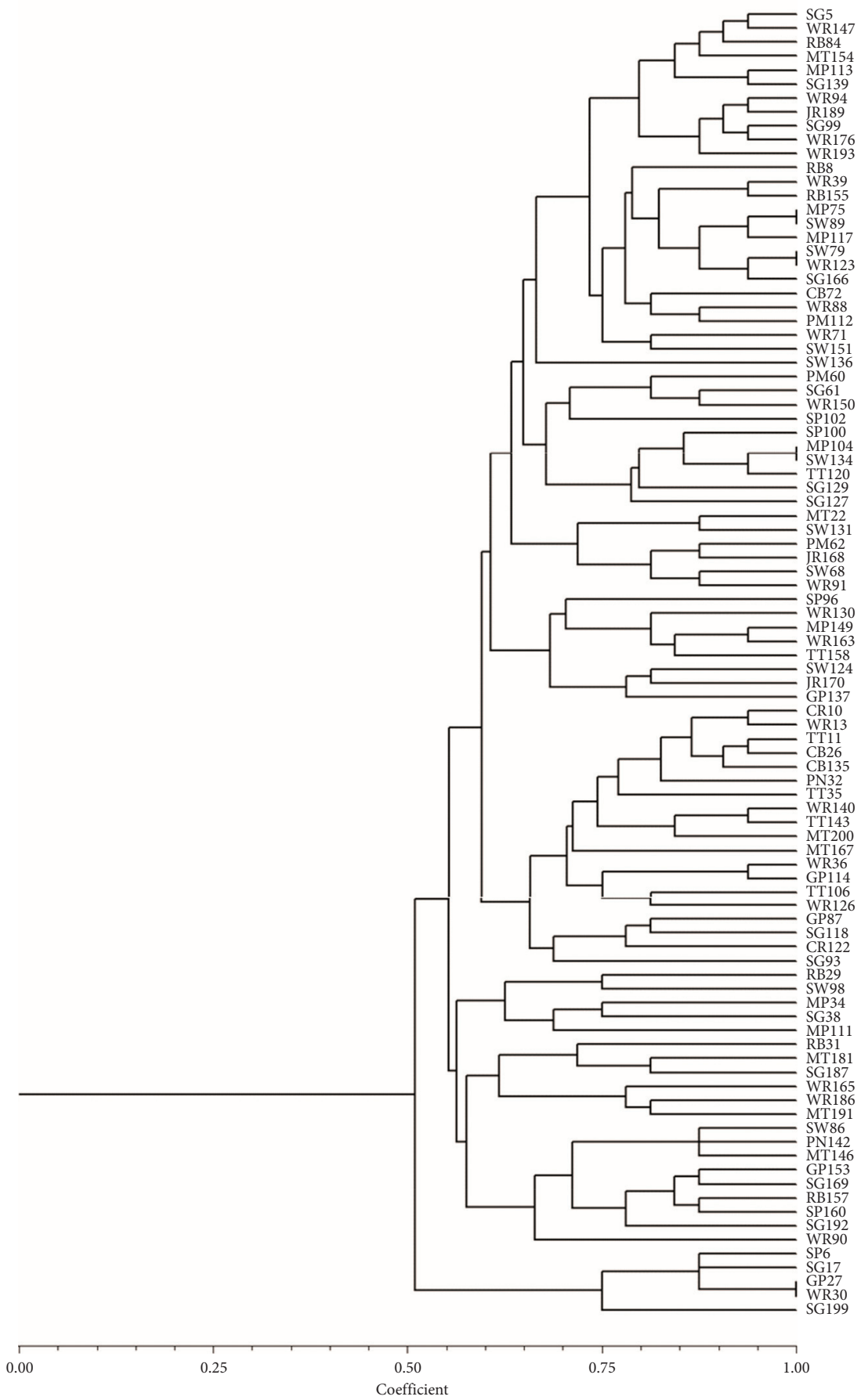

FIGURE 2: Dendrogram from computer-assisted analysis of RAPD-PCR profiles obtained for Bacillus cereus isolates.

\section{Results}

3.1. Genetic Profiling. Results from Agarose gel electrophoresis using Randomly Amplified Polymorphic DNAPCR (RAPD-PCR) for the genetic profiling of the isolates showed that many of the isolates expressed multiple bands characteristic of RAPD-PCR (Figures 1(a)-1(c)). Some showed a single band while others did not show any band at all. Some of the isolates on the lanes $\mathrm{SP}_{5}, \mathrm{WR}_{36}, \mathrm{WR}_{39}$, $\mathrm{MP}_{75}, \mathrm{SW}_{89}, \mathrm{MP}_{113}, \mathrm{WR}_{130}, \mathrm{SW}_{136}, \mathrm{WR}_{150}, \mathrm{MT}_{154}, \mathrm{WR}_{176}$, $\mathrm{JR}_{189}, \mathrm{WR}_{193}, \mathrm{SW}_{89}, \mathrm{SG}_{99}$, and $\mathrm{SW}_{98}$ showed pronounced single bands with an amplified fragment of about $750 \mathrm{bp}$ (Figure 1). The dendrogram generated from computer analysis of the RAPD-PCR using the NTSYS software revealed that all the bacteria are closely related while those grouped together, that is, $\mathrm{MP}_{75}$ and $\mathrm{SW}_{89}$, only showed single band and $\mathrm{SW}_{79}$ and $\mathrm{WR}_{123}$ did not produce any band while $\mathrm{GP}_{27}$ and $\mathrm{WR}{ }_{30}, \mathrm{MP}_{104}$ and $\mathrm{SW}_{134}$ are the same strain (Figure 2). The OPR13 primer used for the genetic profiling gave a good representation. Many of the isolates showed multiple bands characteristic of RAPD-PCR. Oh et al. [11] employed RAPD-PCR using the OPR13 primer 
TABLE 1: B. cereus isolates accession number and the source of the samples.

\begin{tabular}{|c|c|c|c|c|c|}
\hline $\begin{array}{l}\text { Isolate } \\
\text { code }\end{array}$ & $\begin{array}{l}\text { Accession } \\
\text { number }\end{array}$ & $\begin{array}{l}\text { Source of food } \\
\text { sample }\end{array}$ & Closest relative & $\begin{array}{c}\text { Homology } \\
(\%)\end{array}$ & $\begin{array}{l}\text { Access code of the reference strain in } \\
\text { the gene bank }\end{array}$ \\
\hline $\mathrm{RB}_{8}$ & KX574760 & Runner bean & $\begin{array}{l}\text { Bacillus cereus strain MS-Deb- } \\
\text { PCB-Bac-1 }\end{array}$ & 100 & MN545143 \\
\hline $\mathrm{RB}_{29}$ & KX574761 & Runner bean & Bacillus cereus strain SLG2 & 97.04 & MT043919 \\
\hline $\mathrm{RB}_{31}$ & KX574762 & Runner bean & Bacillus cereus strain EG4 & 99.66 & KY435707 \\
\hline $\mathrm{MP}_{111}$ & KX574763 & Meat pie & Bacillus cereus isolate HKS 4-2 & 93.38 & DQ289062 \\
\hline $\mathrm{RB}_{137}$ & KX574764 & Runner bean & Bacillus cereus strain LCB & 94.47 & FJ867921 \\
\hline $\mathrm{RB}_{157}$ & KX574765 & Runner bean & Bacillus cereus strain XJ22 & 87.30 & KC510021 \\
\hline $\mathrm{MT}_{167}$ & KX574766 & Meat & $\begin{array}{c}\text { Bacillus proteolyticus strain } \\
\text { SUF.04LB }\end{array}$ & 100 & MT052616 \\
\hline $\mathrm{JR}_{168}$ & KX574767 & Jollof rice & Bacillus cereus strain AMc01NA & 97.38 & MT052656 \\
\hline $\mathrm{MT}_{200}$ & KX574768 & Meat & Bacillus cereus strain BCHA20 & 88.22 & MT533450 \\
\hline $\mathrm{GP}_{87}$ & KX574769 & Green pea & Bacillus cereus ATCC 14579 & 91.34 & MT421927 \\
\hline $\mathrm{SG}_{5}$ & KX610811 & Spaghetti & Bacillus cereus strain ZMC6 & 99.41 & MN555358 \\
\hline $\mathrm{PM}_{60}$ & KX610812 & Smoked hide & Bacillus cereus strain GL34 & 99.47 & MK099886 \\
\hline $\mathrm{MP}_{113}$ & KX610813 & Meat pie & Bacillus cereus strain S19 & 94.58 & MN879950 \\
\hline $\mathrm{GP}_{114}$ & KX610814 & Green pea & Bacillus cereus strain D21 & 99.06 & KC441762 \\
\hline $\mathrm{WR}_{123}$ & KX610815 & Cooked rice & Bacillus sp strain UFSC-40S1 & 96.51 & MT269024 \\
\hline $\mathrm{SW}_{124}$ & KX610816 & $\begin{array}{l}\text { Smoked African } \\
\text { chad }\end{array}$ & Bacillus cereus strain Ism37 & 99.75 & KP988025 \\
\hline $\mathrm{SG}_{127}$ & KX610817 & Spaghetti & $\begin{array}{l}\text { Bacillus cereus strain MS-Deb- } \\
\text { PCB-Bac-1 }\end{array}$ & 100 & MN545143 \\
\hline $\mathrm{SG}_{129}$ & KX610818 & Spaghetti & Bacillus cereus strain LZH-F21 & 100 & MN099150 \\
\hline $\mathrm{RB}_{155}$ & KX610819 & Runner bean & Bacillus cereus strain LE6 & 99.61 & MT279464 \\
\hline $\mathrm{SG}_{169}$ & KX610820 & Spaghetti & Bacillus cereus strain BAL34 & 93.08 & KP717398 \\
\hline $\mathrm{WR}_{140}$ & MT757957 & Cooked rice & Bacillus cereus strain MD152 & 100 & MT642947 \\
\hline $\mathrm{WR}_{126}$ & MT757958 & Cooked rice & Bacillus cereus strain MD152 & 100 & MT642947 \\
\hline $\mathrm{WR}_{88}$ & MT757959 & Cooked rice & Bacillus cereus strain S8 & 100 & MT611946 \\
\hline $\mathrm{TT}_{106}$ & MT757960 & Smoked titus & Bacillus cereus strain MD152 & 100 & MT642947 \\
\hline $\mathrm{WR}_{13}$ & MT757961 & Cooked rice & Bacillus cereus strain MD152 & 100 & MT642947 \\
\hline $\mathrm{SG}_{92}$ & MT757962 & Spaghetti & Bacillus cereus strain L2C3 & 100 & MN961108 \\
\hline $\mathrm{SG}_{118}$ & MT757963 & Spaghetti & Bacillus cereus strain MD152 & 100 & MT642947 \\
\hline $\mathrm{SG}_{139}$ & MT772282 & Spaghetti & Bacillus cereus strain S8 & 100 & MT611946 \\
\hline $\mathrm{SG}_{99}$ & MT772283 & Spaghetti & Bacillus cereus strain MD152 & 99.85 & MT642947 \\
\hline $\mathrm{RB}_{84}$ & MT772284 & Runner bean & Bacillus cereus strain MD152 & 100 & MT642947 \\
\hline
\end{tabular}

for typing of Bacillus isolates. Their B. cereus strains were classified into 19 banding patterns. They reported that the RAPD patterns obtained with OPR13 distinguished better than OPA3. RAPD and Pulsed-Field Gel Electrophoresis (PFGE) were used to assess the similarity between emetic B. cereus strains. Seventeen (17) distinct banding patterns were obtained, while 10 strains did not give any banding pattern with PFGE [27]. Also, in this research, five strains $\mathrm{SW}_{79}, \mathrm{MP}_{117}, \mathrm{WR}_{123}, \mathrm{RB}_{155}$, and $\mathrm{SG}_{166}$ did not give any bands, but the ImageLab software was able to detect bands for $\mathrm{MP}_{117}$ and $\mathrm{SG}_{166}$. Strains $\mathrm{WR}_{123}$ and $\mathrm{SW}_{79}$ did not produce any band based on the analysis, while the remaining three clustered very close to them. Ghelradi et al. [28] also used RAPD-PCR to identify $B$. cereus to the strain level and concluded that the method is useful in describing intraspecific changes among organisms.

3.2.16S rDNA Identification of B. cereus. The universal couple of primers F1/R2 was able to detect the $16 \mathrm{~S}$ region of the isolates with a molecular size of $1500 \mathrm{bp}$. The Basic Local Alignment Search Tool (BLAST) result that has the highest similarity with the biological sequence in the National Centre for Biotechnology Information (NCBI) database was recorded as the identity of the isolates. The sequences deposited in GenBank with their accession numbers and source of each isolate are presented in Table 1. The isolates were identified as Bacillus cereus. Oh et al. used the universal primer F27/R1492 and reported that their strains have high similarity with members of the B. cereus group in the GenBank.

3.3. Phylogenetic Relationship of B. cereus. The phylogenetic relationship between $B$. cereus and the very closely related strains from the GenBank were analyzed using NeighbourJoining (NJ) and MaximumLikelihood (ML) trees (Figures 3 and 4). The percentage of replicate trees in which the associated taxa clustered together in the bootstrap test (1000 replicates) is shown next to the branches. All positions greater than $50 \%$ are shown. The two trees were employed to establish the proven resolution and statistical significance of the various treeing algorithms $[29,30]$. The $\mathrm{NJ}$ tree revealed that $\mathrm{RB}_{8}, \mathrm{PM}_{60}$, $\mathrm{GP}_{114}, \mathrm{WR}_{123}, \mathrm{SW}_{124}, \mathrm{SG}_{127}, \mathrm{RB}_{137}, \mathrm{RB}_{155}$, and $\mathrm{MT}_{167}$ 


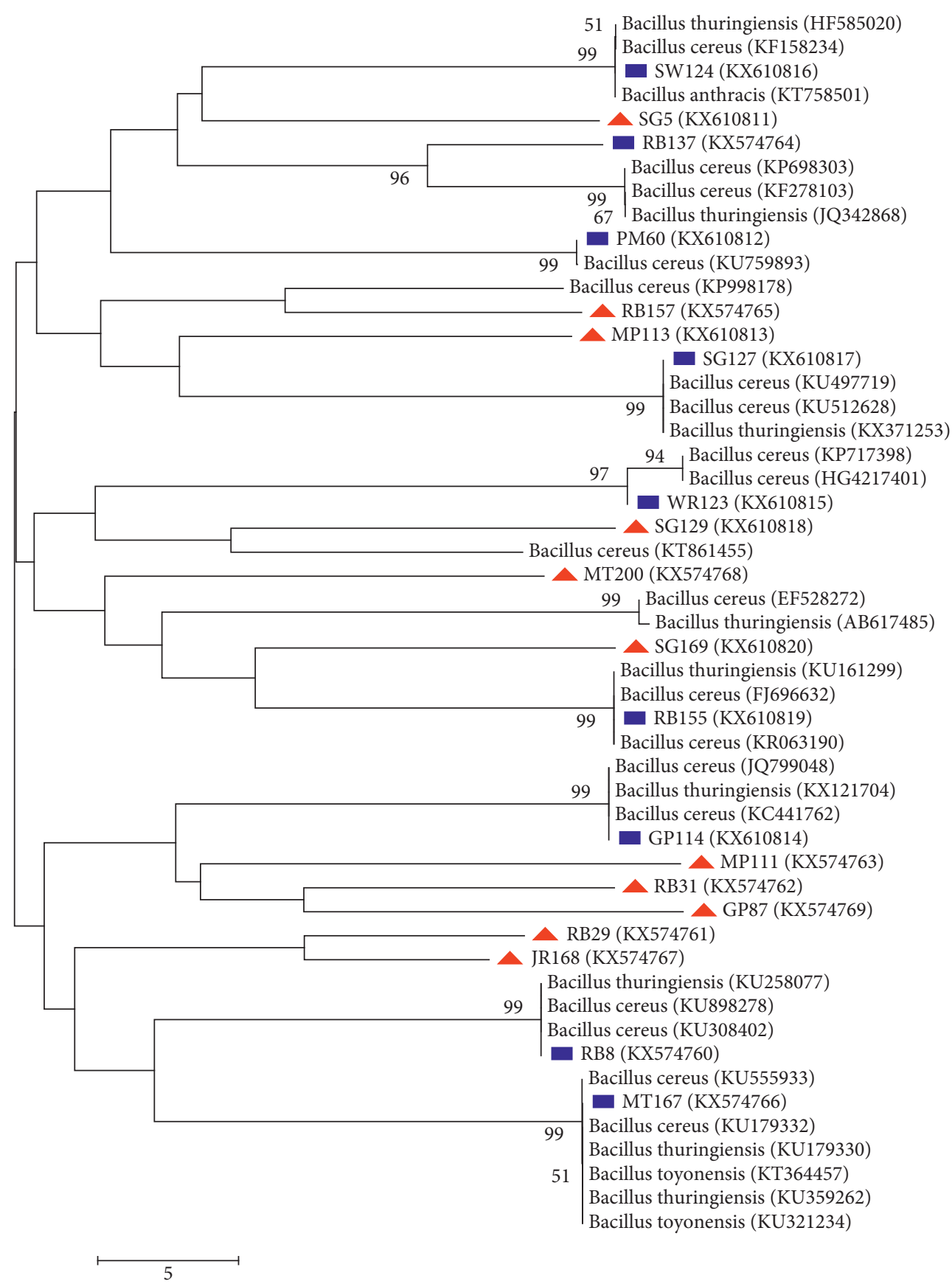

Figure 3: Neighbour-Joining method of phylogenetic tree based on the partial 16S rDNA gene sequence, showing the phylogenetic relationships between the Bacillus cereus and the most closely related strains from the GenBank. Sequences obtained in this study higher than $90 \%$ are denoted with rectangle and lower than $50 \%$ with a triangle.

displayed high bootstrap values greater than $90 \%$ with their relatives $B$. cereus in the GenBank revealing their similarity percentage. This high bootstrap value expressed by the aforementioned Bacillus spp. is beyond $70 \%$ borderline of the degree of relatedness proposed by [31]. Furthermore, $\mathrm{SG}_{5}, \mathrm{RB}_{29}, \mathrm{RB}_{31}, \mathrm{GP}_{87}, \mathrm{MP}_{111}, \mathrm{MP}_{113}$, $\mathrm{SG}_{129}, \mathrm{JR}_{168}$, and $\mathrm{SG}_{169}$ form distinct clades with a bootstrap value lower than $50 \%$ but with closest relative to $B$. cereus. They did not cluster with any strains as a result of their nucleotide signature pattern peculiarity, which is in line with the findings of [32]. This distinctiveness calls for their novelty as reported by [30]. This NJ result was based on a cluster-based algorithm utilized in calculating the pairwise distance between sequences and group sequences that are most similar. For clearness, the character-based method (Maximum Likelihood) chooses the best model for the variation pattern of the sequences by correlating a set of data against the set of models of evolution [33]. The ML tree showed that $\mathrm{PM}_{60}, \mathrm{GP}_{114}$, $\mathrm{WR}_{123}, \mathrm{SW}_{124}, \mathrm{SG}_{127}, \mathrm{RB}_{137}$, and $\mathrm{MT}_{167}$ possessed a very 


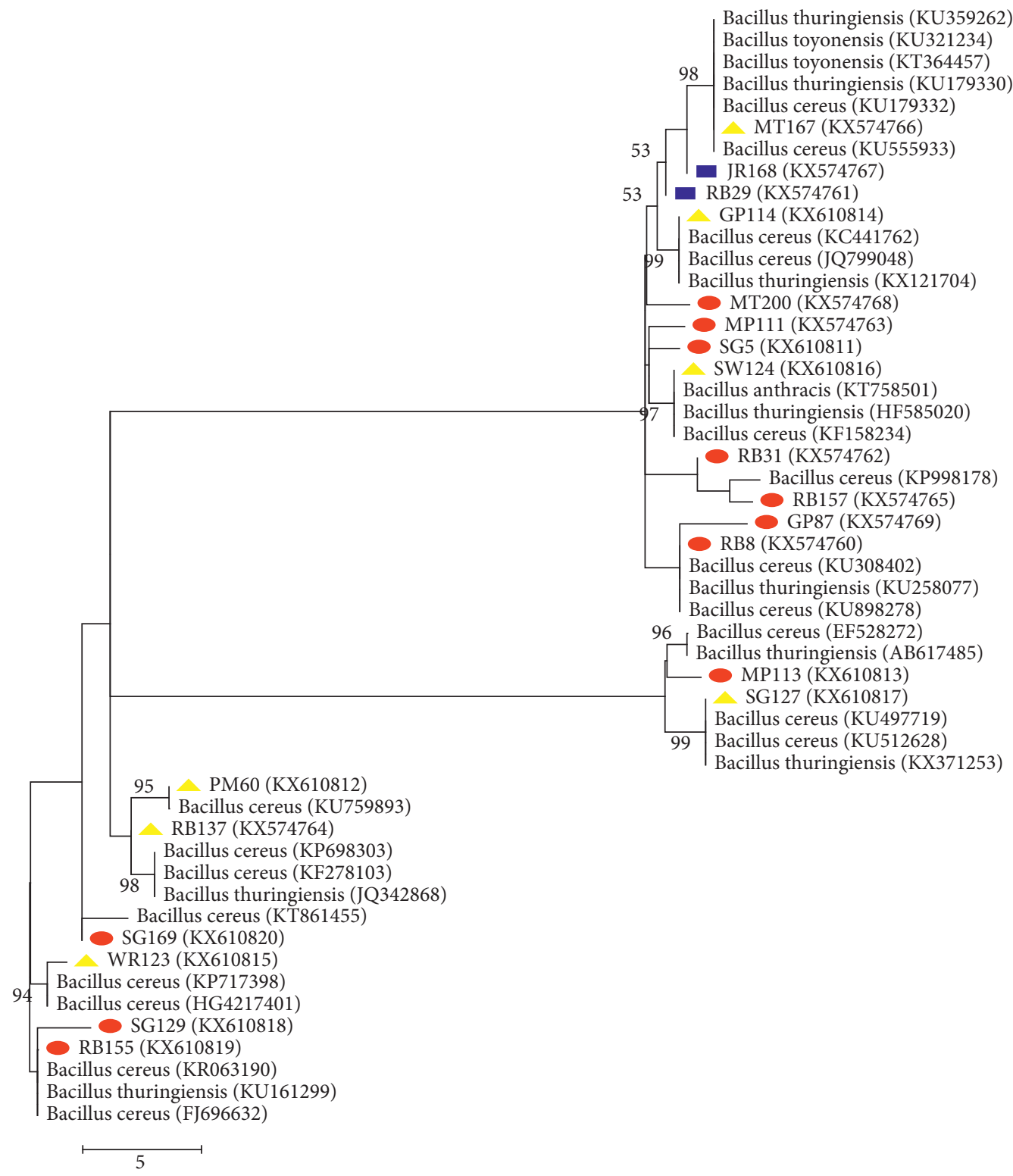

Figure 4: Maximum Likelihood phylogenetic tree based on partial 16S rDNA gene sequence, showing the phylogenetic relationships between the Bacillus cereus and the most closely related strains from GenBank. Sequences obtained in this study higher than $90 \%$ are denoted with the yellow triangle, greater than $50 \%$, but lower than $80 \%$ with the blue rectangle and less than $50 \%$ with a red circle.

high similarity percentage greater than $90 \%$ with $B$. cereus of the reference sequences from the GenBank. This compares well with the result obtained from the NJ with the exception of $\mathrm{RB}_{8}$ and $\mathrm{RB}_{155}$ that exhibited lower than $50 \%$ homology with their Bacillus relatives. This may be as a result of mutation.Hence, the relationship between these strains and their Bacillus spp. relatives has been wiped out [30]. ML deduced that $\mathrm{RB}_{29}$ and $\mathrm{JR}_{168}$ have very low similarity percentage with their relative, which is almost the same with the NJ tree. This is not reliable because their DNA reassociation is above the threshold level based on the result depicted by the ML tree [34]. ML tree also showed that some B. cereus from this research did not align with any of the reference taxa based on their uniqueness. These include $\mathrm{SG}_{5}, \mathrm{RB}_{8}, \mathrm{RB}_{31}$, $\mathrm{GP}_{87}, \mathrm{MP}_{111}, \mathrm{MP}_{113}, \mathrm{SG}_{129}, \mathrm{RB}_{155}, \mathrm{RB}_{157}, \mathrm{SG}_{169}$, and $\mathrm{MT}_{200}$. These eleven isolates are likely to be a far relative of $B$. cereus strains because they possessed distinct nucleotide signature from their relatives in the GenBank.

\section{Conclusions}

This research has shown that some of the isolates are the same as revealed by the dendrogram generated for the RAPD profile. Eleven of the strains form a distinct clade that can never be deduced with conventional methods. The $B$. cereus isolates are associated with foods such as runner bean and 
green pea, which are used in the preparation of fried rice, while meat pie is one of the snacks consumed by people to satisfy hunger. Extra caution must be taken when preparing foods with these ingredients, and snacks such as meat pie should be consumed when hot to prevent food poisoning.

\section{Data Availability}

The data used to support the findings of this study were deposited at NCBI GenBank.

\section{Conflicts of Interest}

The authors declare that there are no conflicts of interest regarding the publication of this paper.

\section{Acknowledgments}

The authors appreciate the financial support from the Tertiary Education Trust Fund (TETFUND) through the University Management of Olabisi Onabanjo University, Ago-Iwoye, and also partial contribution by Prof. Olubukola O. Babalola. They are also grateful to Drs Mobolaji F. Adegboye, Bukola R. Aremu, and Ayansina S. Ayangbenro of Microbial Biotechnology laboratory, North-West University, South Africa, for the assistance rendered during the molecular work.

\section{References}

[1] S. Vilain, Y. Luo, M. B. Hildreth, and V. S. Brözel, "Analysis of the life cycle of the soil saprophyte Bacillus cereus in liquid soil extract and in soil," Applied and Environmental Microbiology, vol. 72, no. 7, pp. 4970-4977, 2006.

[2] S. Das, P. K. Surendran, and N. Thampuran, "PCR-based detection of enterotoxigenic isolates of Bacillus cereus from tropical seafood," The Indian Journal of Medical Research, vol. 129 , no. 3, pp. 316-320, 2009.

[3] S. V. Desai and M. C. Varadaraj, "Prevalence of toxigenic traits in native food isolates of Bacillus cereus in the city of Mysore, Southern India," Journal of Microbiology and Antimicrobials, vol. 1, pp. 27-34, 2009.

[4] Y.-B. Park, J.-B. Kim, S.-W. Shin et al., "Prevalence, genetic diversity, and antibiotic susceptibility of Bacillus cereus strains isolated from rice and cereals collected in Korea," Journal of Food Protection, vol. 72, no. 3, pp. 612-617, 2009.

[5] T. Lindbäck and P. E. Granum, "Detection and purification of Bacillus cereus enterotoxins," "Detection and purification of Bacillus cereus enterotoxins," in Food-Borne Pathogens: Methods and Protocols, C. Adley, Ed., pp. 15-26, Humana Press,, Totowa, NJ, USA, 2006.

[6] I. Jenson, C. J. Moir, and A. D. Hocking, "Bacillus cereus and other Bacillus species," Foodborne Microorganisms of Public Health Significance, vol. 6, pp. 445-478, 2003.

[7] A. Lapidus, E. Goltsman, S. Auger et al., "Extending the Bacillus cereus group genomics to putative food-borne pathogens of different toxicity," Chemico-Biological Interactions, vol. 171, no. 2, pp. 236-249, 2008.

[8] D. A. Rasko, J. Ravel, O. A. Okstad et al., "The genome sequence of Bacillus cereus ATCC 10987 reveals metabolic adaptations and a large plasmid related to Bacillus anthracis
pXO1," Nucleic Acids Research, vol. 32, no. 3, pp. 977-988, 2004.

[9] C. A. Beesley, C. L. Vanner, L. O. Helsel, J. E. Gee, and A. R. Hoffmaster, "Identification and characterization of clinical Bacillus spp. isolates phenotypically similar to Bacillus anthracis," FEMS Microbiology Letters, vol. 313, no. 1, pp. 47-53, 2010.

[10] Z. Zhang, L. Wang, H. Xu et al., "Detection of non-emetic and emetic Bacillus cereus by propidium monoazide multiplex PCR (PMA-mPCR) with internal amplification control," Food Control, vol. 35, no. 1, pp. 401-406, 2014.

[11] M.-H. Oh, J.-S. Ham, and J. M. Cox, "Diversity and toxigenicity among members of the Bacillus cereus group," International Journal of Food Microbiology, vol. 152, no. 1-2, pp. 1-8, 2012.

[12] E. Helgason, O. A. Økstad, D. A. Caugant et al., "Bacillus anthracis, Bacillus cereus, and Bacillus thuringiensis-One Species on the Basis of Genetic Evidence," Applied and Environmental Microbiology, vol. 66, no. 6, pp. 2627-2630, 2000.

[13] M.-H. Guinebretière, F. L. Thompson, A. Sorokin et al., "Ecological diversification in the Bacillus cereus group," Environmental Microbiology, vol. 10, no. 4, pp. 851-865, 2008.

[14] E. Helgason, N. J. Tourasse, R. Meisal, D. A. Caugant, and A.-B. Kolstø, "Multilocus sequence typing scheme for bacteria of the Bacillus cereus group," Applied and Environmental Microbiology, vol. 70, no. 1, pp. 191-201, 2004.

[15] X. Didelot, M. Barker, D. Falush, and F. G. Priest, "Evolution of pathogenicity in the Bacillus cereus group," Systematic and Applied Microbiology, vol. 32, no. 2, pp. 81-90, 2009.

[16] N. J. Tourasse, E. Helgason, A. Klevan et al., "Extended and global phylogenetic view of the Bacillus cereus group population by combination of MLST, AFLP, and MLEE genotyping data," Food Microbiology, vol. 28, no. 2, pp. 236-244, 2011.

[17] O. O. Babalola, E. C. Osir, and A. I. Sanni, "Characterization of potential ethylene-producing rhizosphere bacteria of Striga-infested maize and sorghum," African Journal of Biotechnology, vol. 1, no. 2, pp. 67-69, 2002.

[18] N. Senthil Kumar and G. Gurusubramanian, "Random amplified polymorphic DNA (RAPD) markers and its applications," Science Vision, vol. 11, no. 3, pp. 116-124, 2011.

[19] C. F. Ajilogba and O. O. Babalola, "RAPD Profiling of Bacillus spp with PGPR potential and their effects on mineral composition of tomatoes," Journal of Human Ecology, vol. 56, no. 1-2, pp. 42-54, 2016.

[20] S. Whelan, P. Liò, and N. Goldman, "Molecular phylogenetics: state-of-the-art methods for looking into the past," Trends in Genetics, vol. 17, no. 5, pp. 262-272, 2001.

[21] B. Kulin, R. Meggersee, J. D‘Alton et al., "Prevalence of gastrointestinal pathogenic bacteria in patients with diarrhoea attending Groote Schuur hospital, Cape Town, South Africa," South Africa Medical Journal, vol. 105, no. 2, pp. 121-125, 2015.

[22] R. S. Ronimus, L. E. Parker, and H. W. Morgan, "The utilization of RAPD-PCR for identifying thermophilic and mesophilic Bacillus species," FEMS Microbiology Letters, vol. 147, no. 1, pp. 75-79, 1997.

[23] D. Daffonchio, S. Borin, G. Frova, P. L. Manachini, and C. Sorlini, "PCR fingerprinting of whole genomes: the spacers between the $16 \mathrm{~S}$ and $23 \mathrm{~S}$ rRNA genes and of intergenic tRNA gene regions reveal a different intraspecific genomic variability of Bacillus cereus, Bacillus licheniformis," International Journal of Systematic Bacteriology, vol. 48, no. 1, pp. 107-116, 1998.

[24] S. Altschul, T. L. Madden, A. A. Schäffer et al., "Gapped BLAST and PSI-BLAST: a new generation of protein database 
search programs," Nucleic Acids Research, vol. 25, no. 17, pp. 3389-3402, 1997.

[25] K. Katoh and H. Toh, "Parallelization of the MAFFT multiple sequence alignment program," Bioinformatics, vol. 26, pp. 1899-1900, 2010.

[26] K. Tamura, G. Stecher, D. Peterson, A. Filipski, and S. Kumar, "MEGA6: Molecular evolutionary genetics analysis version 6.0," Molecular Biology and Evolution, vol. 30, no. 12, pp. 2725-2729, 2013.

[27] J.-B. Kim, J.-S. Park, M.-S. Kim, S.-C. Hong, J.-H. Park, and D.-H. Oh, "Genetic diversity of emetic toxin producing $\mathrm{Ba}$ cillus cereus Korean strains," International Journal of Food Microbiology, vol. 150, no. 1, pp. 66-72, 2011.

[28] E. Ghelardi, F. Celandroni, S. Salvetti, C. Barsotti, A. Baggiani, and S. Senesi, "Identification and characterization of toxigenic Bacillus cereusisolates responsible for two food-poisoning outbreaks," FEMS Microbiology Letters, vol. 208, no. 1, pp. 129-134, 2002.

[29] B. J. Tindall, R. Rosselló-Móra, H.-J. Busse, W. Ludwig, and P. Kampfer, "Notes on the characterization of prokaryote strains for taxonomic purposes," International Journal of Systematic and Evolutionary Microbiology, vol. 60, no. 1, pp. 249-266, 2010.

[30] K. T. Konstantinidis and E. Stackebrandt, "Defining taxonomic ranks,"“Defining taxonomic ranks," in The Prokaryotes, E. Rosenberg, E. F. Delong, E. Stackebrandt, S. Lory, and F. Thompson, Eds., Springer, Berlin, Germany, 2013.

[31] L. G. Wayne, D. J. Brenner, R. R. Colwell et al., "Report of the Ad Hoc Committee on Reconciliation of Approaches to Bacterial Systematics," International Journal of Systematic and Evolutionary Microbiology, vol. 37, no. 4, pp. 463-464, 1987.

[32] B. R. Aremu and O. O. Babalola, "Construction of specific primers for rapid detection of South African exportable vegetable macergens," International Journal of Environmental Research and Public Health, vol. 12, no. 10, pp. 12356-12370, 2015.

[33] H. C. Jill and J. A. Langdale, "A step by step guide to phylogeny reconstruction,” The Plant Journal, vol. 45, pp. 561572, 2006.

[34] E. Stackebrandt, W. Frederiksen, G. M. Garrity et al., "Report of the ad hoc committee for the re-evaluation of the species definition in bacteriology," International Journal of Systematic and Evolutionary Microbiology, vol. 52, no. 3, pp. 1043-1047, 2002. 